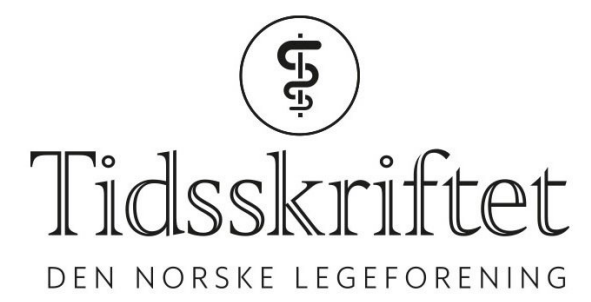

\title{
Når en mindreårig pasient nekter livreddende behandling
}

\author{
MEDISINSK ETIKK

\section{MARIT HELLEBOSTAD} \\ E-post: mhellebostad@online.no \\ Marit Hellebostad (f. 1949) er spesialist i barnesykdommer og dr. med. Hun har arbeidet ved \\ barneavdelingene ved Nordland sentralsykehus i Bodø, Ålesund sjukehus, Ullevål sykehus, \\ Rikshospitalet og fra 2012 Drammen sykehus frem til 1.1.2017. \\ Forfatter har fylt ut ICMJE-skjemaet og oppgir ingen interessekonflikter.
}

\section{ASLAK SYSE}

Aslak Syse (f. 1946) er cand. med., cand. jur. og dr. juris. Han har arbeidet i legestillinger i Finnmark 1972-1988, blant annet som overlege i Helsevernet for psykisk utviklingshemmede (HVPU). Fra 1989 har han arbeidet ved Institutt for offentlig rett, Universitetet i Oslo, fra 1997 som professor, fra 2016 som emeritus.

Forfatter har fylt ut ICMJE-skjemaet og oppgir ingen interessekonflikter.

\section{REIDUN FØRDE}

Reidun Førde (f. 1950) er dr. med. Hun arbeider som professor ved Senter for medisinsk etikk, Institutt for helse og samfunn, Universitetet i Oslo, med spesielt ansvar for nasjonal oppbygging av klinisk etikk i helsetjenesten.

Forfatter har fylt ut ICMJE-skjemaet og oppgir ingen interessekonflikter.

Kan man behandle en livstruende syk pasient over 16 år mot vedkommendes vilje?

Følgende fiktive pasienthistorie illustrerer hvilke etiske og rettslige dilemmaer som kan oppstå i møte med pasienter mellom 16 og 18 år med livstruende sykdommer, når pasientene ikke ønsker livreddende behandling.

Kim, som akkurat har fylt 16 år, får en sjelden og livstruende sykdom med svært god prognose dersom medisinsk behandling startes opp tidlig etter diagnostisering. Behandlingen medfører bivirkninger og er svært langvarig, men har relativt liten risiko. Uten behandling er tilstanden dødelig.

Kim bor hjemme sammen med foreldrene. Familien er svært opptatt av alternativ behandling, og mor betviler umiddelbart legenes diagnose. Hun setter straks i gang tiltak for å utrede alternative diagnoser, noe som forsinker oppstarten av den medisinske behandlingen. Etter utvidet utredning og innhenting av «second opinion» kan den medisinske behandlingen av Kims sykdom starte.

Første del av behandlingen går fint. Kim samarbeider godt, og sykdommen responderer godt på behandlingen. Ved oppstart av neste behandlingsfase er både Kim og mor skeptiske og hevder at de stoler mer på alternativ behandling som vil kunne mobilisere kroppens 
egne helbredende evner, og som har langt mindre bivirkninger. De ønsker derfor å avslutte den påbegynte medisinske behandlingen. De informeres både sammen og hver for seg om de alvorlige konsekvensene av ikke å fullføre behandlingen, men Kim står fast på sin beslutning om å takke nei til videre behandling.

Legene prøver på alle måter å få en allianse med Kim. De opplever at Kim er sterkt påvirket av sin mor. Far er unnvikende, fortvilet, fremstår ambivalent, og han gjør ingen forsøk på å prøve å få Kim til å akseptere fortsatt behandling.

Barnevernet kontaktes flere ganger, men konkluderer med at Kim er beslutningskompetent til å ta helserettslige avgjørelser på egne vegne, og at de derfor har lite å bidra med.

Sykehusets jurister og jurister i tilsynsmyndighetene kontaktes av helsepersonellet, men intet kommer ut av dette.

Etter en tid dør Kim. De ansvarlige legene spør seg om noe kunne vært håndtert annerledes.

\section{Hvem er berørte parter?}

Mange blir berørt i denne saken: Kim som dør, som mest sannsynlig kunne vært reddet og levd et langt liv, mor og far som må leve med vissheten om at Kim kunne vært reddet om de hadde oppmuntret Kim til å akseptere den medisinske behandlingen, søsken som lider under tapet av Kim, og helsepersonell som har brukt mye tid, ressurser og følelser for å redde Kim.

Ikke å redde et ungt liv når behandlingsmulighetene er så gode, er en krenkelse av deres profesjonsetiske kodeks. De behandlingsansvarlige sitter igjen med frustrasjon, skyldfølelse og mange spørsmål.

\section{Hvilke verdier, hensyn og juridiske føringer er involvert?}

I dette tilfellet blir velgjørenhetsprinsippet og ikke skade-prinsippet «ofret» til fordel for respekten for pasientens autonomi. I prinsippet om respekt for pasientens autonomi ligger krav om at pasienten må forstå informasjonen som er gitt, forstå at informasjonen gjelder ham eller henne, og også forstå hvilke konsekvenser fravalget av behandling har.

Man kan stille spørsmål om Kim i denne situasjonen, alvorlig syk og emosjonelt avhengig av og påvirket av mor og mors forestillingsverden, virkelig var beslutningskompetent. Det er stor forskjell på modenhet og selvstendighet hos 16-åringer. Her var det er et sterkt forhold mellom mor og Kim, og det er sannsynlig at mors sterke antipati mot tradisjonell medisin har påvirket Kim slik at Kim ikke har vært uten ytre press, noe som er en av forutsetningene for å kunne utøve autonomi (1).

Dersom Kim hadde vært tvunget til å motta behandling, kan man ikke utelukke at vedkommende ville følt det som et overgrep, og at ikke skade-prinsippet (i alle fall på kort sikt) ville vært truet. Man kan anta at det å påtvinge ungdom livsnødvendig behandling mange ganger vil bli akseptert i ettertid.

Kan Kims tilfelle sammenlignes med behandling av ungdom med alvorlige spiseforstyrrelser? I begge tilfeller er det snakk om en livstruende tilstand med god prognose for overlevelse forutsatt riktig behandling, og de etiske dilemmaene man står overfor, er absolutt sammenlignbare (2). Men ut fra rettslige betraktninger er denne sammenligningen ikke gyldig, da ungdom med alvorlige spiseforstyrrelser kan tvangsbehandles for å redde liv og unngå alvorlig skade. Når denne tilstanden er alvorlig nok, oppfattes dette som en betydelig sinnslidelse i psykisk helsevernlovens forstand, og loven åpner både for tvangsinnleggelse og tvangsernæring, noe som er akseptert av Høyesterett i en viktig dom fra 2015 (3). Dette var også lagt til grunn i juridisk teori før dommen ble avsagt (4).

Tilfellet kan bedre sammenlignes med 16 år gamle barn av Jehovas vitner. Grensen for selvbestemmelse og for å kunne nekte livreddende behandling i form av blodtransfusjon er her 18 år etter pasient- og brukerrettighetsloven $§ 4-9$ tredje ledd. Her kan helsepersonell, ut 
fra plikten til å yte øyeblikkelig hjelp, etter helsepersonelloven $§ 7$ gi den behandling som fremstår som nødvendig og forsvarlig (5). Den relevante forskjellen er at det må foreligge en øyeblikkelig hjelp-situasjon, dvs. at helsehjelpen må være "påtrengende nødvendig». Behandlingen kan da ikke videreføres etter at øyeblikkelig hjelp-situasjonen er over. Dette gjør bestemmelsen vanskelig overførbar til mer pågående og langvarig behandling av kroniske, men livstruende sykdommer, der pasienter har rett til å nekte videre behandling dersom de oppfatter at behandlingen plager dem så mye at de heller vil akseptere en dårlig prognose.

Det er like fullt et relevant spørsmål hvorfor loven gjør religiøs overbevisning til et spesialtilfelle, når alvorlig syk ungdom som Kim ikke beskyttes mot foreldrene lenger enn til fylte 16 år. For mindreårige under 16 år kan Fylkesnemnda etter barnevernloven § 4-10 pålegge unders $\varnothing$ kelse og behandling dersom et barn lider av en «livstruende eller annen alvorlig sykdom eller skade» dersom foreldrene ikke sørger for dette (6).

Definisjonen av 16-åringer som «myndige» i helserettslig forstand fremstår som paradoksal og lite hensiktsmessig for helsepersonell som behandler barn og ungdom, og som har kjempet for å få utvidet barneavdelingenes ansvarsområde til å omfatte ungdom opp til 18 år. Dette er basert på erfaringen at tenåringer med alvorlig sykdom langt fra er «voksne» i en slik situasjon.

Dersom Kim ikke hadde vært helserettslig myndig, ville vedkommende kanskje vært enda mer prisgitt foreldrenes valg, men det kunne gitt barnevernet et større handlingsrom.

Dersom det hadde vært reist tvil rundt Kims beslutningskompetanse, hadde sannsynligvis forholdet mellom omkostninger og risiko ved tvangsbehandling vært oppveiet av at livet kunne blitt reddet.

Det kan heller ikke utelukkes at om lovverket hadde lagt opp til at Kim ikke kunne motsette seg behandling, ville mor godtatt dette og prøvd å legge forholdene til rette for at behandlingen kunne gjennomføres på en best mulig måte for Kim.

\section{Handlingsalternativer}

I den konkrete situasjonen er det etter loven bare en direkte tilnærming til Kim og foreldrene med all tilgjengelig informasjon som vil kunne føre til et annet resultat. I denne saken er dette alternativet prøvd fullt ut.

Da foreligger det i realiteten ikke så mange handlingsalternativer. Det er ikke hjemmel for å gjennomføre langvarig medisinsk behandling overfor en 16 år gammel pasient som motsetter seg slik behandling, så lenge vedkommende vurderes til å være samtykkekompetent, dvs. kan forstå og vurdere sin egen situasjon. Dette er også den rettslige situasjonen dersom foreldrene skulle ønsket at 16-åringen ville gjennomføre den aktuelle behandlingen. Men i så fall ville helsepersonell og foreldrene vært på «samme parti» når det gjaldt legitimiteten av overtalelse til samtykke.

Etter at alle tillitsskapende tiltak er prøvd, er helsepersonellet stilt litt sjakk matt.

I tråd med økt vektlegging av pasientautonomi vil denne situasjonen kunne oppstå oftere enn tidligere, slik at leger og annet helsepersonell i realiteten blir stående maktesløse, selv når de har effektive behandlingsalternativer å tilby.

Det er et viktig spørsmål om ikke helsepersonell - selv om de opplever det som meningsløst - må akseptere at de ikke lenger har beslutningsmyndigheten i en situasjon som her er beskrevet, at handlingsalternativene er få, og at ingen er tilfredsstillende.

\section{Avsluttende vurderinger}

Forfatterne av denne artikkelen deler seg når det gjelder avsluttende vurderinger. Undertegnede leger (Marit Hellebostad og Reidun Førde) er kritiske til at regelverket overlater den endelige avgjørelsen om behandling til emosjonelt sårbare ungdommer, som 
i realiteten er avhengige av foreldrenes vurderinger og oppfatninger. Resultatet kan, som eksemplet viser, føre til at pasienter ikke får sannsynlig livreddende behandling. De mener at en 18-årsgrense slik den gjelder for barn av Jehovas vitner, er riktigere.

En 16-årsgrense gir foreldre i praksis indirekte mye makt. Hviler autonomi bare på kognitive, ikke også på emosjonelle egenskaper? Et tankeeksperiment er: Hva om mor i dette tilfellet også var lege og fortsatt valgte bort sannsynlig livreddende behandling?

Hvordan ville vi bedømme en slik vurdering etisk, spesielt med bakgrunn i den skjeve maktbalansen som fortsatt finnes mellom foreldre og ungdom? Hva om ungdommen valgte en langsom form for suicid? Ville helsetjenesten og jussen da ha toet sine hender?

Undertegnede jurist (Aslak Syse) mener at hensynet til den unges autonomi, så lenge det er tale om en kognitivt velfungerende ungdom uten alvorlig sinnslidelse, tilsier at en 16 år gammel person i utgangspunktet må ha beslutningsmyndighet i helserettslige spørsmål. Det skal svært gode grunner til å operere med høyere aldersgrenser enn 16 år. Det finnes enkelte slike i regelverket (nyredonasjon, assistert befruktning, kosmetisk kirurgi, sterilisering mv.), uten at det er grunn til å drøfte dette nærmere i denne sammenhengen. Når en bestemmelse synes å fungere optimalt i de aller fleste situasjoner, er det et spørsmål om ikke hensynet til den gode - og praktiserbare - regel vil måtte føre til at denne enkelte ganger fører til et tragisk og unngåelig dødsfall. De aller fleste foreldre er i stand til å se barnas beste som den behandlingen som er basert på vitenskapelig dokumentasjon, og de vil i alle fall ikke aktivt søke å forhindre at barnet mottar adekvat og nødvendig behandling. Det har derfor i virkeligheten ikke vært så mange slike situasjoner som den som gjelder Kim. Alternativet er å gi legene for stor skjønnsfrihet til å gjennomføre en behandling de anbefaler, selv når en samtykkekompetent pasient motsetter seg denne.

Mest sannsynlig vil regjeringen snart foreslå at barn og unges med- og selvbestemmelsesrett skal styrkes i regelverket, et forslag som fikk oppslutning i høringsrunden (7). Barn ned til 12 års alder skal i enkelte situasjoner både gis beslutnings- og nektingskompetanse. Det vil imidlertid ikke gjelde ved den type alvorlige tilstander som denne saken dreier seg om. Her vil selvbestemmelsesretten fremdeles inntre ved fylte 16 år. En samtykkekompetent 16-åring vil videre, etter regelendringer i psykisk helsevernloven fra 1. september 2017, kunne nekte tvangsinnleggelse basert på behandlingsindikasjon (8).

Alternativet for å kunne imøtekomme Kims behandlingsbehov i en situasjon som her, vil kreve lovendringer som hever den helserettslige myndighetsalderen og samtidig fratar foreldrene beslutningsretten på barnets vegne. Samtidig må legene gis økt beslutningsrett over 16- og 17-åringer. Slike lovendringer er ikke i tråd med den økte vektleggingen av mindreåriges rett til med- og selvbestemmelse, senest styrket ved en egen bestemmelse i Grunnloven § 104 fra mai 2014.

\section{LITTERATUR:}

1. Ruyter IK, Førde R, Solbakk JH. Medisinsk og helsefaglig etikk. Oslo: Gyldendal akademisk, 2014: 138-142.

2. Giordano S. Understanding eating disorders. Oxford: Oxford University Press 2005: 261.

3. Høyesteretts dom 25. august 2015, Rt. 2015 s. 913.

https://www.domstol.no/globalassets/upload/hret/avgjorelser/2015/avdeling-avgjorelser-august-2015/s ak-2015-1305-anonymisert.pdf(9-5.2017).

4. Syse A. Psykisk helsevernloven med kommentarer. 2. utg. Oslo: Gyldendal akademisk, 2007: 199.

5. Syse A, Befring AK. Barn kan få blod uten foreldres samtykke. Tidsskr Nor Legeforen 2003; 123: 247.

6. LOV-2005-06-17-65. Lov om endringer i lov 17. juli 1992 nr. 100 om barneverntjenester og lov 13. desember $1991 \mathrm{nr} .81 \mathrm{om}$ sosiale tjenester (sosialtjenesteloven) m.v. § 4-10.

https://lovdata.no/dokument/LTI/lov/2005-06-17-65(9.5.2017). 
7. Helse- og omsorgsdepartementet. Høringsnotat 4. oktober 2016: Høyring - Barn sin rett til medverknad og medråderett etter pasient- og brukarrettslova, helsepersonell si ivaretaking av barn som pårørande og etterlatne, diverse andre endringar i helsepersonellova m.m.

https://www.regjeringen.no/no/dokumenter/hoyring-barn-sin-rett-til-medverknad-og-medraderett-e tter-pasient-og-brukarrettslova-helsepersonell-si-ivaretaking-av-barn-som-parorande-og-etterlatnediverse-andre-endringar-i-helsepersonellova-m.m/id2513591/(9.5.2017).

8. LOV-2017-02-10-6. Lov om endringer i psykisk helsevernloven mv. ( $\varnothing \mathrm{kt}$ selvbestemmelse og rettssikkerhet). https://lovdata.no/dokument/NL/lov/2017-02-10-6 (9.5.2017).

Publisert: 21. august 2017. Tidsskr Nor Legeforen. DOI: 10.4045/tidsskr.17.0247

Mottatt 14.3.2017, første revisjon innsendt 26.3.2017, godkjent 9.5.2017.

(C) Tidsskrift for Den norske legeforening 2020. Lastet ned fra tidsskriftet.no 